\title{
Antimicrobial Activities of Ferrocenyl Complexes: A Review
}

\author{
Ashraf S. Hassan*, Taghrid S. Hafez \\ Organometallic and Organometalloid Chemistry Department, National Research Centre, Dokki, 12622 Cairo, Egypt.
}

\begin{tabular}{|c|c|}
\hline ARTICLE INFO & ABSTRACT \\
\hline $\begin{array}{l}\text { Article history: } \\
\text { Received on: } 24 / 12 / 2017 \\
\text { Accepted on: } 18 / 03 / 2018 \\
\text { Available online: } 30 / 05 / 2018\end{array}$ & $\begin{array}{l}\text { Bioorganometallic chemistry was devoted to the synthesis of new organometallic compounds and their biological } \\
\text { and medicinal activities. Ferrocenyl complexes display various pharmacological interests such as antibacterial and } \\
\text { antifungal activities. This review article will focus on antimicrobial activities of ferrocenyl complexes (Cu, Co, Ni, } \\
\text { and } \mathrm{Zn} \text { ). }\end{array}$ \\
\hline $\begin{array}{l}\text { Key words: } \\
\text { Ferrocene compounds, } \\
\text { Metal complexes, Ferrocenyl } \\
\text { complexes, Antimicrobial } \\
\text { agents. }\end{array}$ & \\
\hline
\end{tabular}

\section{INTRODUCTION}

Organometallic chemistry is of growing interest especially in the recent decades due to its wide applications in the biological and medicinal field, this application leads to a new area called bioorganometallic chemistry. Ferrocene moiety is used in bioorganometallic chemistry due to its stability, biological activity and application in organic synthesis to prepare new compounds. Also, metal complexes are used in bioorganometallic chemistry since they exhibit a wide range of biological activities against various diseases.

Since the discovery of ferrocene $\mathbf{1}$ in 1951 (Kealy and Pauson, 1951), ferrocene and its derivatives have attracted the attention of many researchers in the field of organometallic chemistry for using in various applications such as materials science (Kadkin et al., 2007; Ochi et al., 2010), bio-organometallic and biological chemistry (Sudhir et al., 2010; Molina et al., 1999; Patra et al., 2010), nonlinear optics (Morales-Espinoza et al., 2010), asymmetric catalysis (Sondenecker et al., 2011), polymer science as redox active polymers (Hudson, 2001), electrochemistry

${ }^{*}$ Corresponding Author

Ashraf S. Hassan, Organometallic and Organometalloid Chemistry Department, National Research Centre, Dokki, 12622 Cairo, Egypt. E-mail:ashraf_salmoon@yahoo.com
(Zheng et al., 2013; Qiao et al., 2009), corrosion inhibition (Gupta et al., 2014) and molecular recognition as biosensors (Beer et al., 1992; Beer and Smith, 1998; Moore et al., 1993).

Many ferrocene compounds display interesting antibacterial (Kazemizadeha et al., 2016), antifungal (Dou et al., 2008), antimalarial (Itoh et al., 2000; Kumar et al., 2014), antitumor (Hafez et al., 2013; Long et al., 2009), antioxidant (Hussain et al., 2013) and cytotoxic (Hassan et al., 2015a; Abd El-All et al., 2016) activities. Also, ferrocene compounds appeared promising in biological activities. For example, ferroquine 2 (FQ, SR97193), is a new antimalarial (Dive and Biot, 2008). Compound 3 is a potent antifungal agent and showed $100 \%$ inhibitory ratios against $S$. sclerotiorum, P. oryzae and C. cucumerinum (Liu et al., 2008). Compound 4, 3-ferrocenoyl-1-(4-trifluoromethoxyphenyl) urea, shows a potential in vitro antitumor activity using reported method (Skehan et al., 1990) against cervical carcinoma cells (KB cells) (Chen et al., 2005) and compound 5, 1-(4-chlorophenyl)-3ferrocenylurea, showed potential anti-HIV protease activity (Liu et al., 2012) (Figure 1).

On the other hand, the biological activities of metal complexes have gained attention during the last two decades due to their diverse biomedical applications like antibacterial (Osman et al., 2012; Sakthilatha et al., 2015; Wakil et al., 2017), antifungal (Ran et al., 2011; El-Tabl et al., 2012), cytotoxicity (Osman et 
al., 2014; El-Seidy et al., 2013), antitumor (Chang et al., 2015; Rubino et al., 2016), antiviral (Abou-Melha et al., 2015), DNA cleavage (Kokare et al., 2017; Subbaraj et al., 2014), antimalarial
(Hubin et al., 2014), antioxidant (Abdel-Monem et al., 2017; Lakshmi et al., 2011), analgesic and anti-inflammatory (Hoonur et al., 2010; 2011) activities.

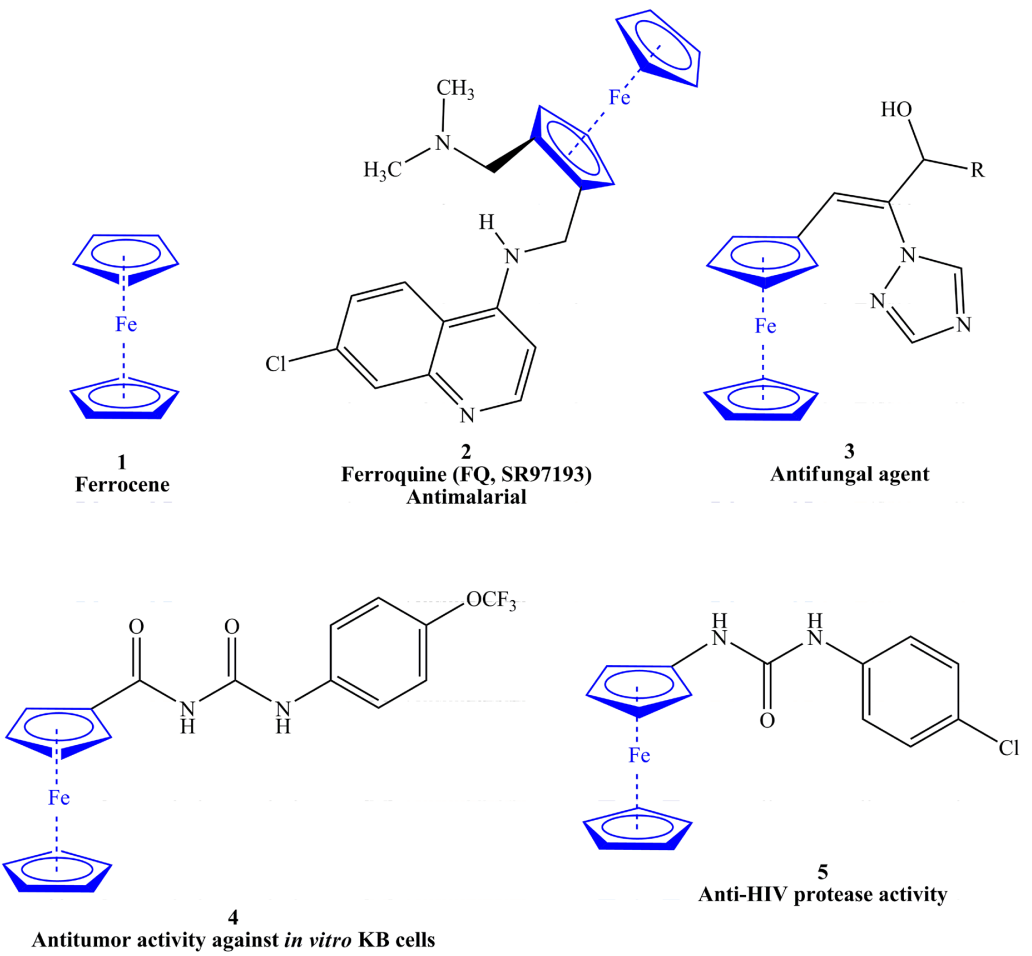

Fig. 1: Structure of ferrocene $\mathbf{1}$ and its derivatives with biological activities 2-5.

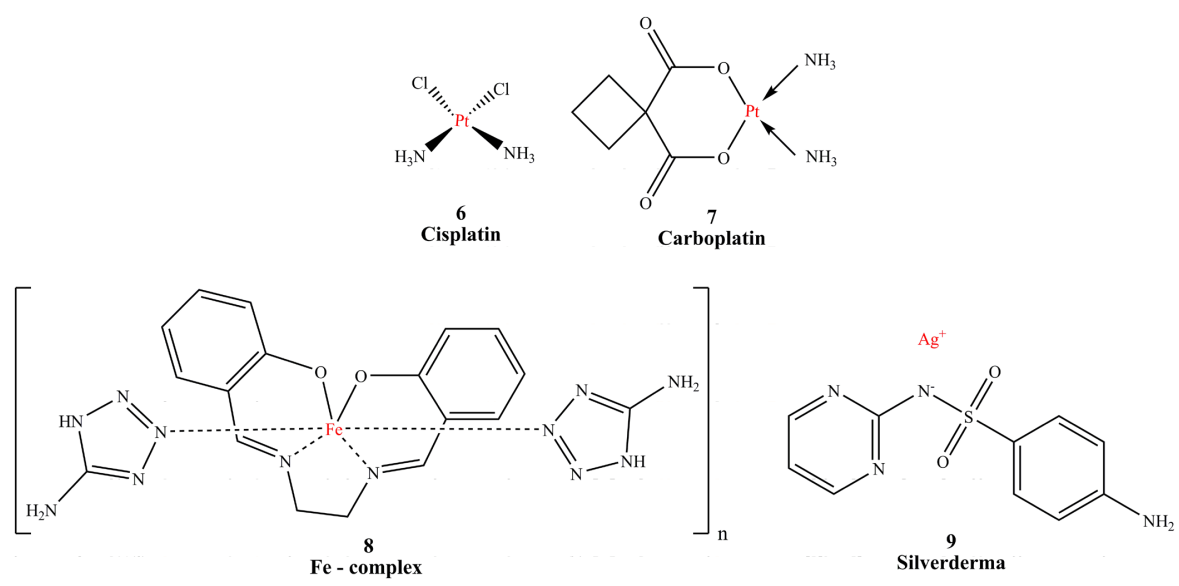

Fig. 2: Structure of some metal complexes with biological activities 6-9.

Cisplatin (6), cis- $\left[\mathrm{PtCl}_{2}\left(\mathrm{NH}_{3}\right)_{2}\right]$, is the most famous and the best-known example of a small molecule-metal complex that has been used in the chemotherapy for various cancer diseases (Ott and Gust, 2007). Carboplatin (7) entered the clinic in 1998; it is a chemotherapy drug that is used against human cancer cell lines (mainly, ovarian carcinoma, lung, head, and neck cancers). Complex (8) was the most active against leukemia (K562) and breast (MCF-7) cells with $\mathrm{IC}_{50}=6.4 \pm 1.2$ and $13.1 \pm 2.1 \mu \mathrm{M}$, respectively, it was more active than the standard drug, oxaliplatin $\left(\mathrm{IC}_{50}=9.0\right.$ and $\left.18.0 \mu \mathrm{M}\right)$ (Herchel et al., 2009). Also, silverderma (silver complex of sulfadiazine) (9) was used as an antifungal drug (Figure 2).
Vitamin B12 (cobalamin) (10) (Figure 3) has been proved to be an essential complex with various health benefits. Among its benefits are (i) supporting the formation of red blood cells, (ii) maintaining healthy and properly functioning nerve tissues, (iii) treatment of cyanide poisoning and hereditary deficiency of transcobalamin II, and (iv) protect against brain atrophy. For the treatment of cyanide poisoning, sufficiently large amounts of hydroxocobalamin may be administered intravenously. Hydroxocobalamin can also be provided together with sodium thiosulfate (Hall and Rumack, 1987) to deliver a similar effect. The toxic cyanide ion replaces the hydroxycobalamin hydroxide ligand, and the resulting 
benign B12 complex is passed with urine. This treatment was approved in fact by the US Food and Drug Administration (FDA) in 2006 to address acute treatment of cyanide poisoning (Dart, 2006). It was also noted (Vogiatzoglou et al., 2008) that high vitamin B12 level in the elderly could provide protection against negative effects of Alzheimer's disease on the brain (including atrophy or shrinkage associated with and impaired cognitive function).

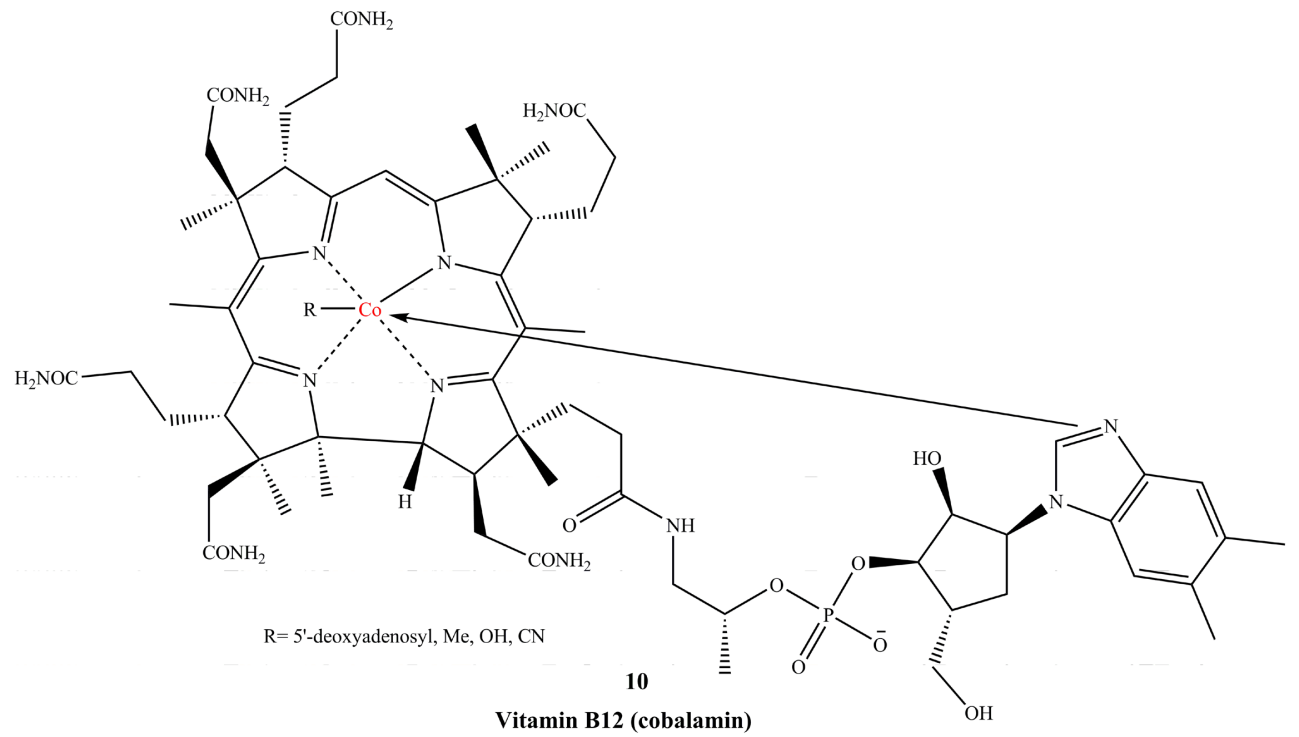

Fig. 3: Structure of vitamin B12 (cobalamin) 10.

From the previous biological effectiveness of ferrocene compounds and metal complexes as well as our research program to display the biological activities of compounds (Hassan et al., 2015b; 2015c; 2016; 2017a; 2017b; 2017c; Elgemeie et al., 2008). The main objective of this review is to display the antimicrobial activities of ferrocenyl complexes.

\section{The effectiveness of ferrocenyl complexes $(\mathrm{Cu}, \mathrm{Co}, \mathrm{Ni}, \mathrm{Zn})$ as antimicrobial agents}

Antimicrobial drugs have been successfully used for treating patients with micro-organism diseases, but, the major problem is that the microbes have become resistant to these drugs. Therefore, it is too important to design and synthesize new drugs or develop the used drugs by introducing and/or omitting different atoms to change the chemical structure for matching these transformations.

Many drugs that are based on biologically active compounds possess modified pharmacological and toxicological characteristics, compared to their original characteristics, when administered as metal-based compounds. Commonly used ions include cobalt, copper, nickel and zinc $\{\mathrm{Cu}, \mathrm{Co}, \mathrm{Ni}, \mathrm{Zn}\}$. These metal complexes have low molecular weight with better effect against several diseases. Some ferrocenyl complexes possess antimicrobial characteristics and can be used as new drugs.

Chohan and Praveen in 2000 and 2001 have synthesized $\mathrm{Co}(\mathrm{II}), \mathrm{Ni}(\mathrm{II}), \mathrm{Zn}(\mathrm{II})$ and $\mathrm{Cu}(\mathrm{II})$ complexes of symmetric and asymmetric 1,1'-ferrocene derived Schiff-bases for their evaluation as antibacterial agents against different microbes e.g. E. coli, S. aureus, P. aeruginosa and K. pneumonae. From the results of antibacterial activity, it was found that $\left[\mathrm{Ni}\left(\mathrm{L}^{1}\right)\right.$ $\left.\left(\mathrm{Cl}_{2}\right)\right]$ and $\left[\mathrm{Co}\left(\mathrm{L}^{3}\right)\left(\mathrm{Cl}_{2}\right)\right]$ complexes were more active than the other prepared complexes against E. coli, while, $\left[\mathrm{Co}\left(\mathrm{L}^{1}\right)\right.$ $\left.\left(\mathrm{Cl}_{2}\right)\right]$ and $\left[\mathrm{Co}\left(\mathrm{L}^{3}\right)\left(\mathrm{Cl}_{2}\right)\right]$ complexes were more active than the remaining prepared complexes against $K$. pneumonae and $E$. coli, respectively. In comparison with the ligands, the metal complexes were found to be more biologically active (Chohan and Praveen, 2000; 2001) (Figure 4).

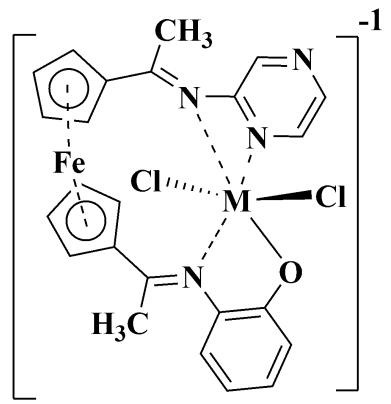

$\mathrm{M}=\mathrm{Co}(\mathrm{II}), \mathrm{Ni}(\mathrm{II})$ or $\mathrm{Zn}(\mathrm{II})$

Fig. 4: Metal complexes of symmetric and asymmetric 1,1'-ferrocene derived Schiff-bases. 
In 2003, Chohan et al., have prepared metal complexes of symmetrically 1,1 '-disubstituted ferrocene derived from Schiffbases for their evaluation as antibacterial agents against $E$. coli, $S$. aureus, $P$. aeruginosa and $K$. pneumoniae. From the results of the antibacterial activity, it was found that $\left[\mathrm{Co}\left(\mathrm{L}^{1}\right)\left(\mathrm{Cl}_{2}\right)\right],\left[\mathrm{Zn}\left(\mathrm{L}^{1}\right)\left(\mathrm{Cl}_{2}\right)\right]$ and $\left[\mathrm{Co}\left(\mathrm{L}^{3}\right)\left(\mathrm{Cl}_{2}\right)\right]$ complexes were more active than the other prepared complexes against E. coli. $\left[\mathrm{Cu}\left(\mathrm{L}^{1}\right)\left(\mathrm{Cl}_{2}\right)\right],\left[\mathrm{Cu}\left(\mathrm{L}^{3}\right)\left(\mathrm{Cl}_{2}\right)\right]$ and $\left[\mathrm{Zn}\left(\mathrm{L}^{3}\right)\left(\mathrm{Cl}_{2}\right)\right]$ complexes were more active than the remaining prepared complexes against $S$. aureus. Complexes of $\left[\mathrm{Ni}\left(\mathrm{L}^{1}\right)\left(\mathrm{Cl}_{2}\right)\right]$ and $\left[\mathrm{Ni}\left(\mathrm{L}^{3}\right)\left(\mathrm{Cl}_{2}\right)\right]$ were active against $P$. aeruginosa. Complexes of
$\left[\mathrm{Co}\left(\mathrm{L}^{1}\right)\left(\mathrm{Cl}_{2}\right)\right],\left[\mathrm{Co}\left(\mathrm{L}^{2}\right)\left(\mathrm{Cl}_{2}\right)\right],\left[\mathrm{Ni}\left(\mathrm{L}^{2}\right)\left(\mathrm{Cl}_{2}\right)\right]$ and $\left[\mathrm{Co}\left(\mathrm{L}^{3}\right)\left(\mathrm{Cl}_{2}\right)\right]$ were active against $K$. pneumonia (Chohan et al., 2003) (Figure 5).

Abd-Elzaher in 2004, synthesized and evaluated the antimicrobial activities of $\mathrm{Co}(\mathrm{II}), \mathrm{Cu}(\mathrm{II}), \mathrm{Ni}(\mathrm{II})$ and $\mathrm{Zn}$ (II) complexes of ferrocenyl Schiff bases bearing a phenol moiety against E. coli, B.subtilus and C. albicans. From the results of antimicrobial evaluation, the prepared complexes of $\mathrm{Cu}(\mathrm{L} 1)_{2}$, $\mathrm{Zn}(\mathrm{L} 1)_{2} \cdot 2 \mathrm{H}_{2} \mathrm{O}, \quad \mathrm{Co}(\mathrm{L} 2)_{2} \cdot 2 \mathrm{H}_{2} \mathrm{O}, \quad \mathrm{Ni}(\mathrm{L} 2)_{2} \cdot 2 \mathrm{H}_{2} \mathrm{O}, \quad \mathrm{Cu}(\mathrm{L} 2)_{2}$ and $\mathrm{Zn}(\mathrm{L} 2)_{2} \cdot 2 \mathrm{H}_{2} \mathrm{O}$ showed significant antimicrobial activity against C. albicans (Abd-Elzaher, 2004) (Figure 6).
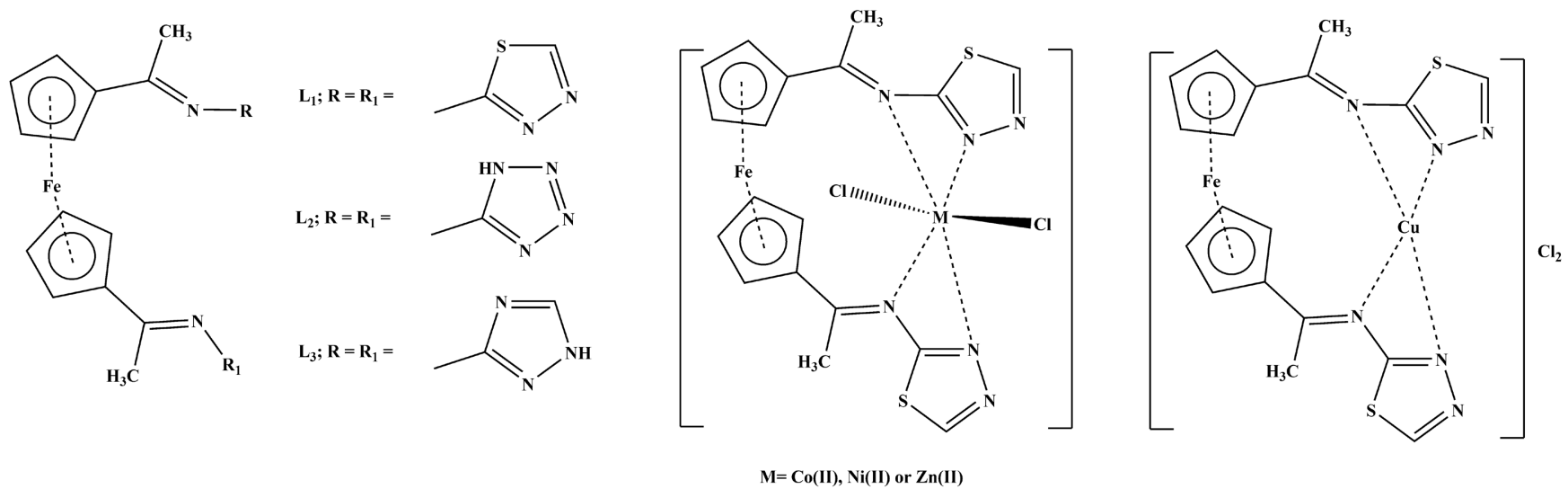

Fig. 5: Metal complexes of symmetrically 1,1'-disubstituted ferrocene derived Schiff-bases.

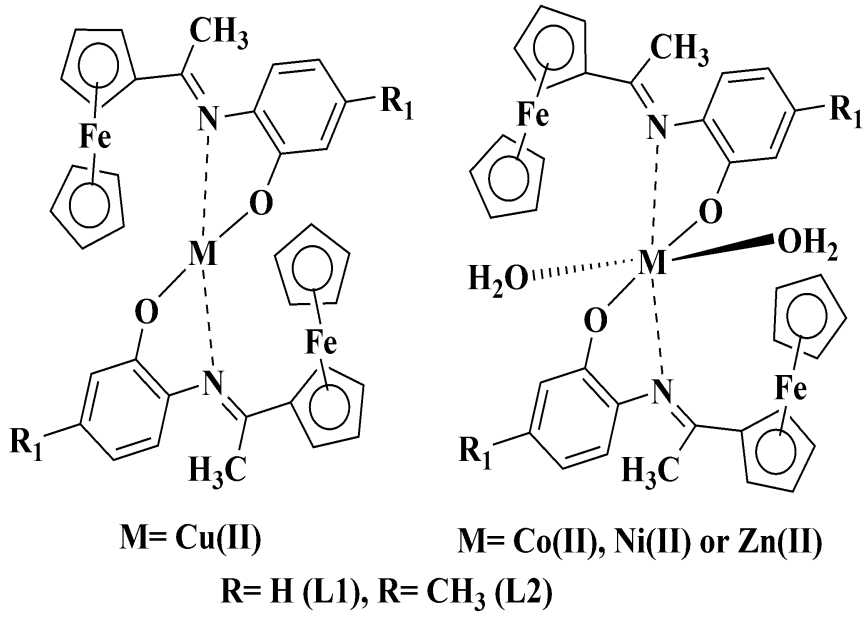

Fig. 6: Metal complexes of ferrocenyl Schiff bases containing a phenol moiety.

In 2017, Mahmoud et al., synthesized metal complexes of $\left[\mathrm{M}(\mathrm{L}) \mathrm{Cl}\left(\mathrm{H}_{2} \mathrm{O}\right)_{3}\right]\{\mathrm{M}=\mathrm{Ni}(\mathrm{II}), \mathrm{Cu}(\mathrm{II})\}$ and $[\mathrm{M}(\mathrm{L})$ $\left.\mathrm{Cl}\left(\mathrm{H}_{2} \mathrm{O}\right)_{3}\right] \cdot \mathrm{nH}_{2} \mathrm{O}\{\mathrm{M}=\mathrm{Co}(\mathrm{II}), \mathrm{n}=1$ and $\mathrm{M}=\mathrm{Zn}(\mathrm{II}), \mathrm{n}=2\}$ of (Z)-(4-(1-((2-carboxycyclohexa-2,4-dien-1-yl)imino)ethyl) [bis( $\eta 5$ cyclopenta-1,3-dien-1 yl)]iron for their evaluation as antimicrobial agents against some bacteria and fungi. From the results of the antimicrobial evaluation, the prepared ferrocenyl complexes exhibited the highest antibacterial and antifungal activities. The antimicrobial activity of ferrocenyl complex depending on the nature of ferrocene derivative, the total charge of the complex, and the metal center in the complex (Mahmoud et al., 2017) (Figure 7).
In 2005, Abd-Elzaher et al., have prepared the complexes of $\mathrm{Co}(\mathrm{II}), \mathrm{Ni}(\mathrm{II}), \mathrm{Cu}(\mathrm{II})$ and $\mathrm{Zn}(\mathrm{II})$ of 1,1'-bis[(2thienylmethylidene)hydrazono-1-ethyl]ferrocene and tested against two Gram-positive, two Gram-negative bacteria, two fungi and one yeast. By comparing the results of antimicrobial activity, it was found that the complexes of $\mathrm{Ni}$ (II), $\mathrm{Cu}$ (II) and $\mathrm{Zn}$ (II) are more active towards $C$. albicans than the Co(II) complex and the $\mathrm{Cu}$ (II) complex is more active than the remaining complexes against S. Typhi (Abd-Elzaher et al., 2005) (Figure 8).

In 2006, Abd-Elzaher et al., and El-shiekh et al., have prepared different metal complexes of 1,1'-bis [1-methyl-5-phenyl$4 H$-(1,3,4)-thiadiazolo[2,3-c](1,2,4)triazin-4-one]ferrocene and 
1,1'-bis[1,5-methyl-4H-(1,3,4)-thiadiazolo[2,3-c](1,2,4)triazin4-one]ferrocene then evaluated their activities against different microbes, e.g., A. niger, C. herbarum, F. moniliforme, E. coli and $S$. aureus. The results revealed that the complexes have higher biological activity than the free ligand and the order of inhibition zone diameter (mm) by the complexes is $\mathrm{Zn}$ (II) $>\mathrm{Cu}$ (II) $>\mathrm{Mn}$ (II) $>\mathrm{Co}(\mathrm{II})>\mathrm{Ni}(\mathrm{II})>\mathrm{Fe}(\mathrm{III})$ (Abd-Elzaher et al., 2006; El-shiekh et al., 2006) (Figure 9).

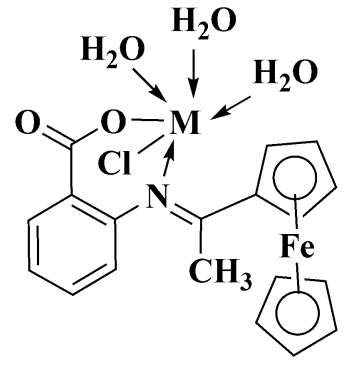

$\left[\mathrm{M}(\mathrm{L}) \mathrm{Cl}\left(\mathrm{H}_{2} \mathrm{O}\right)_{3}\right]$ $\mathbf{M}=\mathbf{N i}($ II), $\mathbf{C u}$ (II)

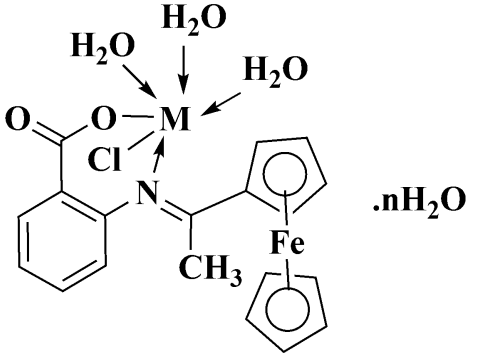

$\left[\mathrm{M}(\mathrm{L}) \mathrm{Cl}\left(\mathrm{H}_{2} \mathrm{O}\right)_{3}\right] \cdot \mathrm{nH}_{2} \mathrm{O}$ $\mathrm{M}=\mathrm{Co}(\mathrm{II}), \mathrm{n}=1$ and $\mathrm{M}=\mathrm{Zn}(\mathrm{II}), \mathrm{n}=\mathbf{2}$

Fig. 7: Metal complexes of ferrocene-based Schiff base ligand.

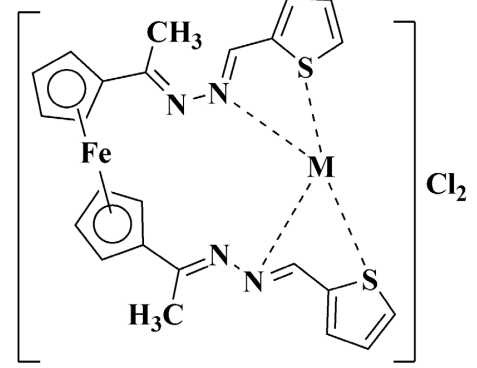

$\mathrm{M}=\mathrm{Ni}(\mathrm{II})$ and $\mathrm{Cu}(\mathrm{II})$

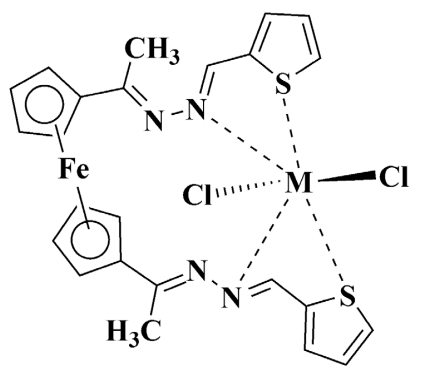

$\mathrm{M}=\mathrm{Co}(\mathrm{II})$ and $\mathrm{Zn}(\mathrm{II})$

Fig. 8: Metal complexes of 1,1'-bis[(2-thienylmethylidene)hydrazono-1-ethyl]ferrocene.

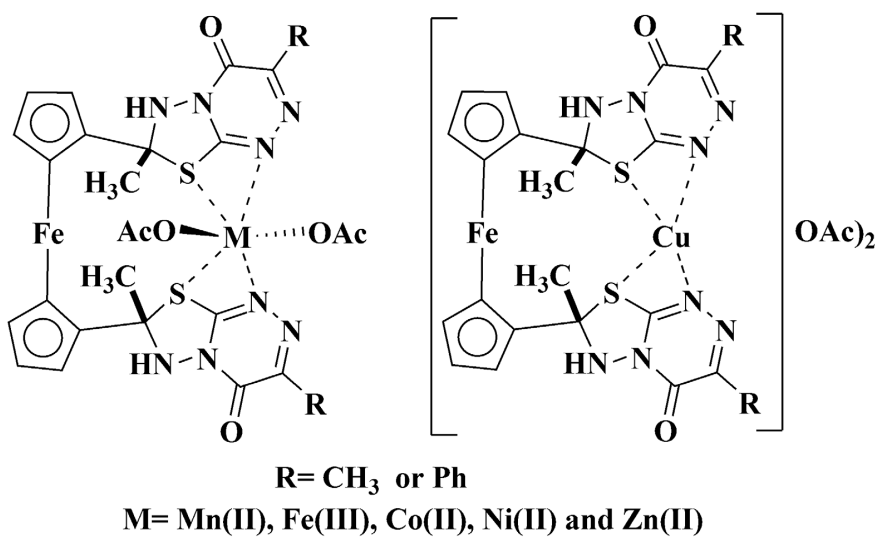

Fig. 9: Metal complexes of 1,1'-bis[1-methyl-5-phenyl-4H-(1,3,4)-thiadiazolo[2,3-c](1,2,4)triazin-4-one]ferrocene and 1,1'-bis[1,5-methyl-4H-(1,3,4)-thiadiazolo[2,3-c](1,2,4)triazin-4-one]ferrocene.

Chohan et al., in 2004, have obtained $\mathrm{Co}(\mathrm{II}), \mathrm{Cu}(\mathrm{II})$, $\mathrm{Ni}(\mathrm{II})$ and $\mathrm{Zn}(\mathrm{II})$ complexes of ferrocenyl hydrazones, bis-(1,1'disubstituted ferrocenyl)thiocarbohydrazone (L1) and bis-(1,1'disubstituted ferrocenyl)carbohydrazone (L2) and tested for antibacterial and antifungal activities. All the prepared complexes showed significant antibacterial and antifungal activities against all the micro-organisms in this study (Chohan et al., 2004) (Figure $10)$.

In 2005, Chohan and Supuran have prepared of Co(II), $\mathrm{Cu}(\mathrm{II}), \mathrm{Ni}(\mathrm{II})$ and $\mathrm{Zn}(\mathrm{II})$ complexes of 1,1'-(dicarbohydrazono) ferrocenes and evaluated their activities against bacterial and fungal strains. The inhibition zones $(\mathrm{mm})$ and the minimum inhibitory concentration (MIC) of some selected compounds were determined by using the disc diffusion method (Atta-ur-Rahman et al., 2001). The experimental results showed that the ferrocenyl complexes were more active than their ligands in inhibiting the growth of the organisms when tested at $10 \mu \mathrm{g} \mathrm{ml}^{-1}$ concentrations (Chohan and Supuran 2005) (Figure 11).

In 2007, Chohan and Naseer have synthesized and screened for their antibacterial and antifungal properties of $\mathrm{Co}$ (II), 
$\mathrm{Cu}(\mathrm{II}), \mathrm{Ni}(\mathrm{II})$ and $\mathrm{Zn}$ (II) complexes of 1-acetyl, 1'-ethanolamine ferrocene and 1,1'-di-ethanolamine ferrocene. All the metal(II) complexes have shown good antibacterial and antifungal activities from moderate to a significant degree (Chohan and Naseer, 2007) (Figure 12).

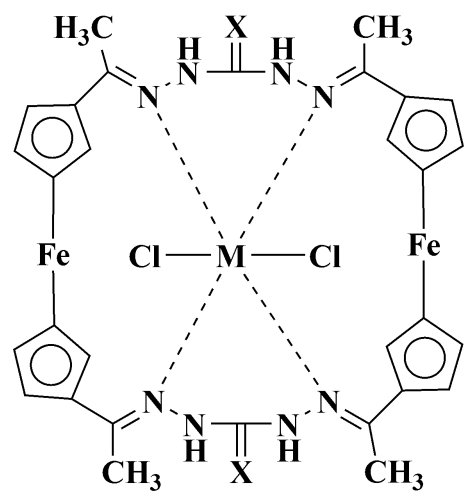

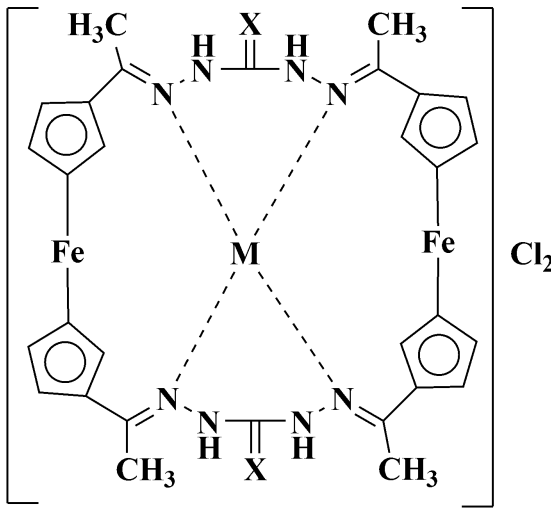

$\mathrm{M}=\mathrm{Co}(\mathrm{II}), \mathrm{Ni}(\mathrm{II})$ and $\mathrm{Zn}(\mathrm{II})$ $\mathbf{X}=\mathbf{O}$ or $\mathbf{S}$

Fig. 10: Metal complexes of new ferrocenyl hydrazones.

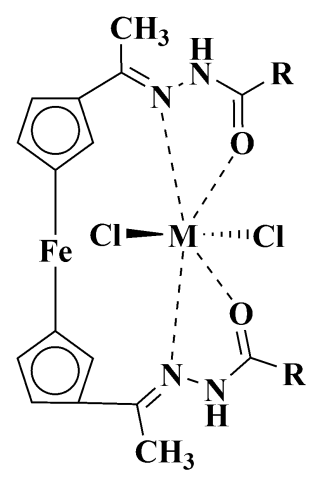<smiles></smiles>

$\mathbf{R}=$<smiles>Cc1ccco1</smiles><smiles>Cc1cccs1</smiles>

or<smiles>Cc1ccccc1O</smiles>

$\mathrm{M}=\mathrm{Co}(\mathrm{II}), \mathrm{Ni}(\mathrm{II})$ and $\mathrm{Zn}(\mathrm{II})$

Fig. 11: Metal complexes of 1,1'-(dicarbohydrazono) ferrocenes.

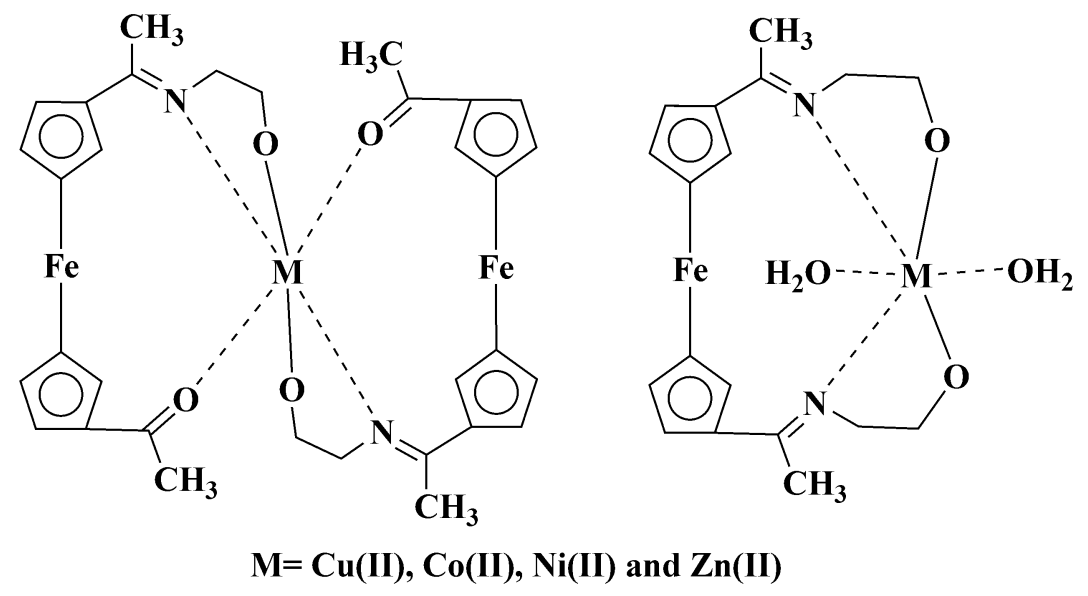

Fig. 12: Metal complexes of 1-acetyl, 1'-ethanolamine ferrocene and 1,1'-di-ethanolamine ferrocene. 
Liu et al., in 2013, have synthesized the metal complexes of $S$-benzyl- $N$-(1-ferrocenyl-3-(4-methylbenzene)acrylketone) dithiocarbazate (HL1) and $S$-benzyl- $N$-(1-ferrocenyl-3-(4chlorobenzene)acrylketone)dithiocarbazate (HL2) and tested for their antibacterial and antifungal properties. The results revealed that $\mathrm{Zn}(\mathrm{II})$ complexes of both the ligands and $\mathrm{Cu}(\mathrm{II})$ complex of the HL2 were shown to have significant activity against all bacterial strains. The minimum inhibitory concentration (MIC) of $\mathrm{Zn}$ (II) and $\mathrm{Cu}$ (II) complexes of ligand (HL2) was in the range of $1.54 \times 10^{-8}$ to $3.750 \times 10^{-7} \mathrm{M}$ while $\mathrm{Zn}$ (II) complex of (HL1) proved to be the most active one and it inhibited the growth of $A$. niger at $1.319 \times 10^{-8} \mathrm{M}$. The metal(II) complexes showed good antifungal activity against different fungal strains (Liu et al., 2013) (Figure 13).

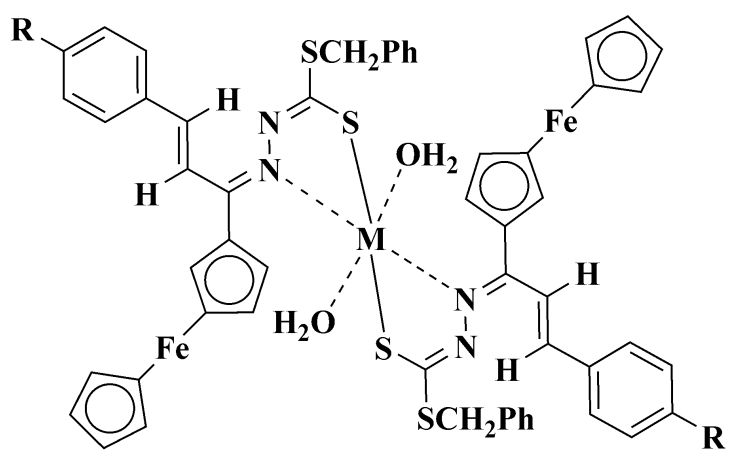

\section{HL1, $\mathrm{R}=\mathrm{CH}_{3} ; \mathrm{HL2}, \mathrm{R}=\mathrm{Cl}$ $\mathrm{M}=\mathrm{Cu}(\mathrm{II}), \mathrm{Co}(\mathrm{II}), \mathrm{Ni}(\mathrm{II})$ and $\mathrm{Zn}(\mathrm{II})$}

Fig. 13: Metal complexes of S-benzyl-N-(1-ferrocenyl-3-(4-methylbenzene)acrylketone) dithiocarbazate (HL1) and S-benzyl-N-(1-ferrocenyl-3-(4-chlorobenzene) acrylketone)dithiocarbazate (HL2).

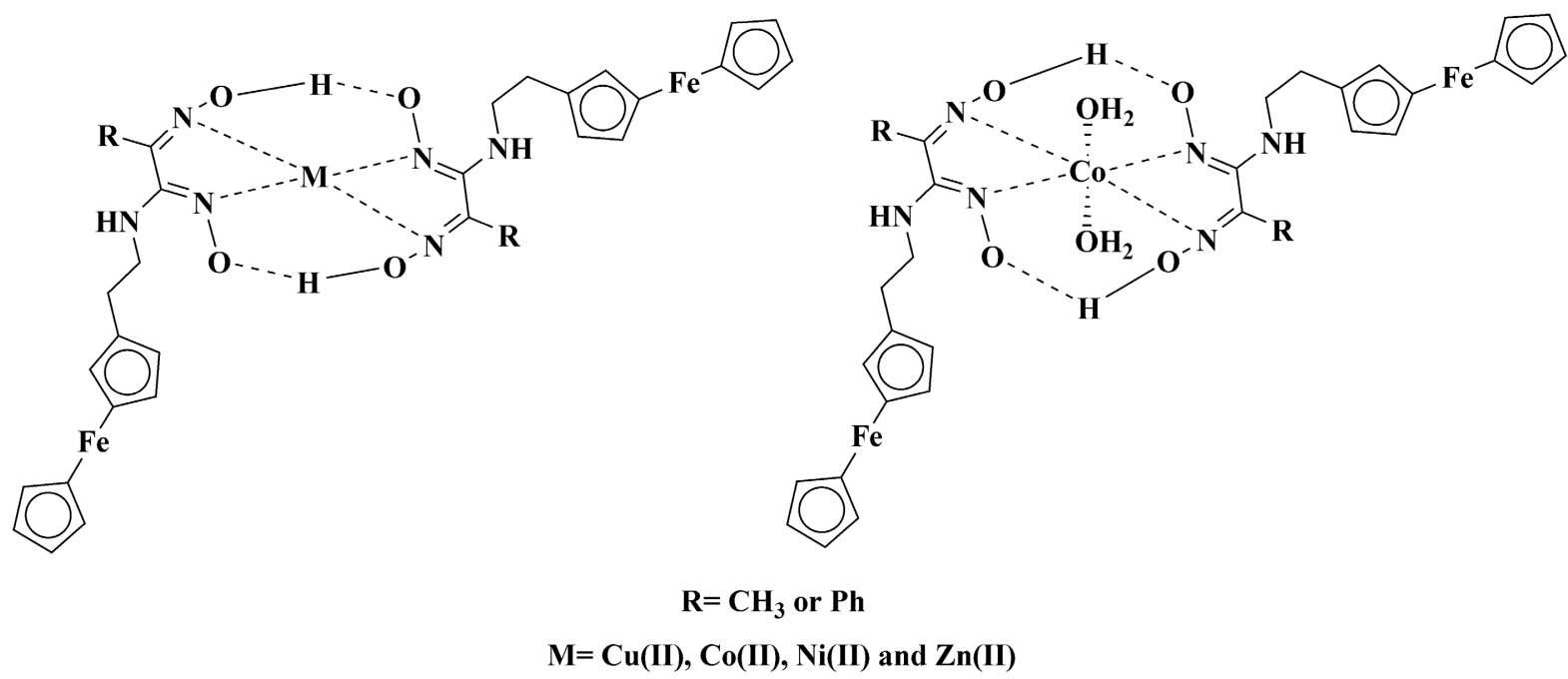

Fig. 14: Metal complexes of anti- $\beta$-ferrocenylethylaminoglyoxime and anti- $\beta$-ferrocenylethylaminophenylglyoxime.

Deveci and Arslanb in 2011, have synthesized $\mathrm{Ni}(\mathrm{II}), \quad \mathrm{Cu}(\mathrm{II})$ and $\mathrm{Co}(\mathrm{II})$ complexes of anti- $\beta$ ferrocenylethylaminoglyoxime and anti- $\beta$-ferrocenylethylami nophenylglyoxime and their antibacterial activity were studied. The results indicated that all the complexes have mild levels of antibacterial activity against gram-negative and gram-positive species and the minimum inhibitory concentrations (MICs) of complexes were found in the range from $32 \mathrm{mg} / \mathrm{ml}$ to $128 \mathrm{mg} / \mathrm{ml}$ (Deveci and Arslanb, 2011) (Figure 14).

In 2015, Ali et al., have synthesized and screened for their in vitro evaluation of antibacterial and antifungal properties $\mathrm{Zn}(\mathrm{II})$, $\mathrm{Cd}(\mathrm{II}), \mathrm{Hg}(\mathrm{II})$ and Pd(II) complexes of 1,1'-(4,4'-di-ferrocenyl)- $d i$-phenyl thiourea. The results indicated that all the complexes are biologically active against Gram-positive, Gram-negative bacteria and yeast (Ali et al., 2015) (Figure 15).

\section{The mode of action}

According to the chelation theory, chelation tends to make the ligands act as more powerful and potent bactericidal agents, thus killing the microorganisms. As such a possible explanation of the results may relate to the polarity of a metal ion and its interaction with a ligand, increasing the lipophilic nature of the metal and enhancing its penetration capacity through the lipid layer of the cell membrane of the microorganism. Furthermore, 
it was proposed that the presence of heteroatom has an important role in promoting antimicrobial activities, and enhancing the hydrophobic and liposolubility characteristics of the overall structure. Other factors, such as solubility, conductivity and dipole moment (influenced by the presence of metal ions), may also be possible reasons for increasing this activity (Abd-Elzaher 2004; Abd-Elzaher et al., 2006).

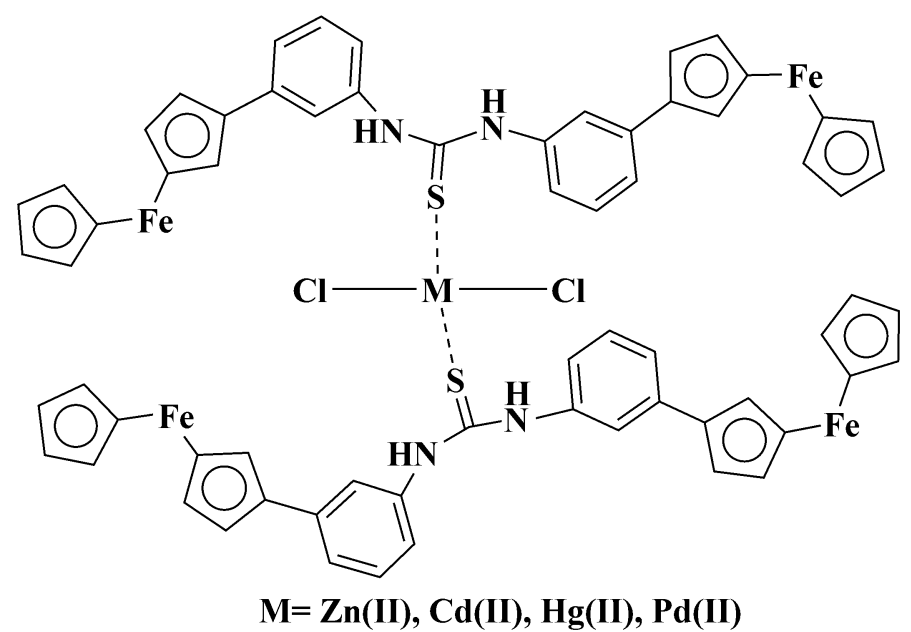

Fig. 15: Metal complexes of 1,1'-(4,4'-di-ferrocenyl)-di-phenyl thiourea.

\section{CONCLUSION}

From this review, it can be concluded that ferrocenyl complexes display pharmacological and medicinal activities as antimicrobial agents against different microbes. The ferrocenyl complexes are more active than the free ligand and this activity depends on the metal ion and the tested microbes. For that, ferrocenyl complexes have attracted increasing attention of the scientists for searching of new potent pharmacological and medicinal activities.

\section{ACKNOWLEDGMENTS}

The authors wish to express their thanks to the National Research Center (the project number 11090112) for the facilities provided.

\section{REFERENCES}

Abd El-All AS, Hassan AS, Osman SA, Yosef HAA, AbdelHady WH, El-Hashash MA, Atta-Allah SR, Ali MM, El Rashedy AA. Synthesis, characterization and biological evaluation of new fused triazine derivatives based on 6-methyl-3-thioxo-1,2,4-triazin-5-one. Acta Pol Pharm, 2016; 73:79.

Abdel-Monem YK, Abou El-Enein SA, El-Sheikh-Amer MM. Design of new metal complexes of 2-(3-amino-4,6-dimethyl-1Hpyrazolo[3,4-b]pyridin-1-yl)aceto-hydrazide: Synthesis, characterization, modelling and antioxidant activity. J Mol Struct, 2017; 1127:386.

Abd-Elzaher MM, El-shiekh SM, Eweis M. Biological studies of newly synthesized ferrocenyl complexes containing triazinone moiety. Appl Organometal Chem, 2006; 20:597.

Abd-Elzaher MM, Hegazy WH, Gaafar AM. Synthesis, characterization and biological studies of ferrocenyl complexes containing thiophene moiety. Appl Organometal Chem, 2005; 19:911.

Abd-Elzaher MM. Synthesis, characterization, and antimicrobial activity of cobalt(II), nickel(II), copper(II) and zinc(II) complexes with ferrocenyl Schiff bases containing a phenol moiety. Appl Organometal Chem, 2004; 18:149.

Abou-Melha K, Refat MS, Sadik A. A series of taurocholic acid complexes, spectral, kinetic, molecular modeling, and antiviral activity studies. Synth React Inorg Met Org Chem, 2015; 45:884.
Ali S, Yasin G, Zuhra Z, Wu Z, Butler IS, Badshah A, Din IU. Ferrocene-based bioactive bimetallic thiourea complexes: synthesis and spectroscopic studies. Bioinorganic Chemistry and Applications, 2015; 2015, Article ID 386587, 9 pages.

Atta-ur-Rahman, Choudhary MI, Thomsen WJ. Bioassay Techniques for Drug Development. Harwood Academic Publishers: The Netherlands, 2001; 16.

Beer PD, Nation JE, Harman ME, Hursthouse MB. Synthesis, electrochemistry and complexation studies of new redox active bisferrocene acyclic and macrocyclic thioethers. J Organomet Chem, 1992; 441:465.

Beer PD, Smith DRJ. Tunable bis(ferrocenyl) receptors for the solution-phase electrochemical sensing of transition-metal cations. J Chem Soc Dalton Trans, 1998; 3:417.

Chang H-Q, Jia L, Xu J, Xu Z-Q, Chen R-H, Wu W-N, Bie H-Y, Zhu T-F, Ma T-1, Wang Y. Syntheses, characterizations, antitumor activities and cell apoptosis induction of $\mathrm{Cu}(\mathrm{II}), \mathrm{Zn}(\mathrm{II})$ and $\mathrm{Cd}(\mathrm{II})$ complexes with hydrazone Schiff base derived from isonicotinohydrazide. Inorg Chem Commun, 2015; 57:8.

Chen L, Wang Q, Huang R, Mao C, Shang J, Song H. Synthesis of ferrocenoylphenylureas and the crystal structure of FcCONHCONHC ${ }_{6} \mathrm{H}_{5}$ Appl. Organometal Chem, 2005; 19:45.

Chohan ZH, Khan KM, Supuran CT. Synthesis of antibacterial and antifungal cobalt(II), copper(II), nickel(II) and zinc(II) complexes with bis-(1,1'-disubstituted ferrocenyl)thiocarbohydrazone and bis-(1,1'disubstituted ferrocenyl)carbohydrazone. Appl Organometal Chem, 2004; 18:305.

Chohan ZH, Naseer MM. Organometallic based biologically active compounds: synthesis of mono- and di-ethanolamine derived ferrocenes with antibacterial, antifungal and cytotoxic properties. Appl Organometal Chem, 2007; 21:1005.

Chohan ZH, Praveen M. Synthesis, characterization and antibacterial properties of symmetric 1,1'-ferrocene derived Schiffbase ligands and their $\mathrm{Co}(\mathrm{II}), \mathrm{Cu}(\mathrm{II}), \mathrm{Ni}(\mathrm{II})$ and $\mathrm{Zn}$ (II) chelates. Appl Organometal Chem, 2000; 14:376.

Chohan ZH, Praveen M. Synthesis, characterization, coordination and antibacterial properties of novel 1,1'-disubstituted ferrocene-derived Schiff-base ligands and their $\mathrm{Co}(\mathrm{II}), \mathrm{Cu}(\mathrm{II}), \mathrm{Ni}(\mathrm{II})$ and $\mathrm{Zn}(\mathrm{II})$ complexes. Appl Organometal Chem, 2001; 15:617.

Chohan ZH, Scozzafava A, Supuran CT. Synthesis of biologically active $\mathrm{Co}(\mathrm{II}), \mathrm{Cu}(\mathrm{II}), \mathrm{Ni}(\mathrm{II})$, and $\mathrm{Zn}(\mathrm{II})$ complexes of symmetrically 
1,1'-disubstituted ferrocene-derived compounds. Synth React Inorg Met Org Chem, 2003; 33:241.

Chohan ZH, Supuran CT. Organometallic compounds with biologically active molecules: in vitro antibacterial and antifungal activity of some 1,1'-(dicarbohydrazono) ferrocenes and their cobalt(II), copper(II), nickel(II) and zinc(II) complexes. Appl Organometal Chem, 2005; 19:1207.

Dart RC. Hydroxocobalamin for acute cyanide poisoning: new data from preclinical and clinical studies; new results from the prehospital emergency setting. Clinical Toxicology, 2006; 44 (Suppl 1):1-3.

Deveci P, Arslanb U. Synthesis of novel ferrocene containing vic-dioxime ligands and their $\mathrm{Ni}(\mathrm{II}), \mathrm{Cu}(\mathrm{II})$ and $\mathrm{Co}(\mathrm{II})$ complexes: Spectral, electrochemical and biological activity studies. J Organomet Chem, 2011; 696:3756.

Dive D, Biot C. Ferrocene conjugates of chloroquine and other antimalarials: the development of ferroquine, a new antimalarial. Chem Med Chem, 2008; 3:383.

Dou Y-Y, Xie Y-F, Tang L-F. Synthesis, electrochemical properties and fungicidal activity of 1,1'-bis(aroyl)ferrocenes and their derivatives. Appl Organometal Chem, 2008; 22:25.

Elgemeie GH, Elsayed SH, Hassan AS. Direct route to a new class of acrylamide thioglycosides and their conversions to pyrazole derivatives. Synth Commun, 2008; 38:2700.

El-Seidy AMA, El-Zahany E, Barakat AS, Youssef NS, Galal SA, Drweesh SA. Synthesis, characterization, and cytotoxic activity on MCF-7 cell line of some novel metal complexes with substituted benzimidazole ligands. Synth React Inorg Met Org Chem, 2013; 43:46.

El-shiekh SM, Abd-Elzaher MM, Eweis M. Synthesis, characterization and biocidal studies of new ferrocenyl thiadiazolotriazinone complexes. Appl Organometal Chem, 2006; 20:505.

El-Tabl AS, Shakdofa MME, El-Seidy AMA, Al-Hakimi AN. Synthesis, characterization and antifungal activity of metal complexes of 2-(5-((2-chlorophenyl)diazenyl)-2-hydroxybenzylidene) hydrazinecarbothioamide. Phosphorus Sulfur and Silicon and the Related Elements, 2012; 187:1312.

Gupta SR, Mourya P, Singh MM, Singh VP. Synthesis, structural, electrochemical and corrosion inhibition properties of two new ferrocene Schiff bases derived from hydrazides. J Organomet Chem, 2014; 767:136.

Hafez TS, Osman SA, Yosef HAA, Abd El-All AS, Hassan AS, El-Sawy AA, Abdallah MM, Youns M. Synthesis, structural elucidation and in vitro antitumor activities of some pyrazolopyrimidines and Schiff bases derived from 5-amino-3-(arylamino)- $1 \mathrm{H}$-pyrazole-4-carboxamides. Sci Pharm, 2013; 81:339.

Hall AH, Rumack BH. Hydroxycobalamin/sodium thiosulfate as a cyanide antidote. J Emerg Med, 1987; 5:115.

Hassan AS, Hafez TS, Ali MM, Khatab TK. Design, synthesis and cytotoxic activity of some new pyrazolines bearing benzofuran and pyrazole moieties. Res J Pharm Biol Chem Sci, 2016; 7:417.

Hassan AS, Hafez TS, Osman SA, Ali MM. Synthesis and in vitro cytotoxic activity of novel pyrazolo[1,5- $a]$ pyrimidines and related Schiff bases. Turk J Chem, 2015a; 39:1102.

Hassan AS, Hafez TS, Osman SA. Synthesis, characterization, and cytotoxicity of some new 5-aminopyrazole and pyrazolo[1,5-a] pyrimidine derivatives. Sci Pharm, 2015c; 83:27.

Hassan AS, Mady MF, Awad HM, Hafez TS. Synthesis and antitumor activity of some new pyrazolo[1,5-a]pyrimidines. Chin Chem Lett, 2017a; 28:388.

Hassan AS, Masoud DM, Sroor FM, Askar AA. Synthesis and biological evaluation of pyrazolo[1,5-a]pyrimidine-3-carboxamide as antimicrobial agents. Med Chem Res, 2017b; 26:2909.

Hassan AS, Moustafa GO, Awad HM. Synthesis and in vitro anticancer activity of pyrazolo[1,5- $a]$ pyrimidines and pyrazolo $[3,4-d]$ $[1,2,3]$ triazines. Synth Commun, 2017c; 47:1963.

Hassan AS, Osman SA, Hafez TS. Phenyl-2-furaldehyde: synthesis, reactions and biological activities. Egypt J Chem, 2015b; 8:113.

Herchel R, Šindelář Z, Trávníček Z, Zbořil R, Vančo J. Novel 1D chain $\mathrm{Fe}(\mathrm{III})$-salen-like complexes involving anionic heterocyclic
$\mathrm{N}$-donor ligands. Synthesis, X-ray structure, magnetic, ${ }^{57} \mathrm{Fe}$ Mössbauer and biological activity studies. Dalton Trans, 2009; 28:9870.

Hoonur RS, Patil BR, Badiger DS, Vadavi RS, Gudasi KB, Chandrashekhar VM, Muchchandi IS. Synthesis, characterization, antiinflammatory and analgesic activity of transitionmetal complexes of 3-[1-(2-hydroxyphenyl)ethylideamino]-2-phenyl-3,4-dihydroquinazolin4(3H)-one. Appl Organometal Chem, 2011; 25:476.

Hoonur RS, Patil BR, Badiger DS, Vadavi RS, Gudasi KB, Dandawate PR, Ghaisas MM, Padhye SB, Nethaji M. Transition metal complexes of 3-aryl-2-substituted 1,2-dihydroquinazolin-4(3H)-one derivatives: New class of analgesic and anti-inflammatory agents. Eur J Med Chem, 2010; 45:2277.

Hubin TJ, Amoyaw PNA, Roewe KD, Simpson NC, Maples RD, Freeman TNC, Cain AN, Le JG, Archibald SJ, Khan SI, Tekwani BL, Khan MOF. Synthesis and antimalarial activity of metal complexes of crossbridged tetraazamacrocyclic ligands. Bioorg Med Chem, 2014; 22:3239.

Hudson RDA. Ferrocene polymers: current architectures, syntheses and utility. J Organomet Chem, 2001; 637:47.

Hussain RA, Badshash A, Sohail M, Lal B, Altaf AA. Synthesis, chemical characterization, DNA interaction and antioxidant studies of ortho, meta and para fluoro substituted ferrocene incorporated selenoureas Inorg Chim Acta, 2013; 402:133.

Itoh T, Shirakami S, Ishida N, Yamashita Y, Yoshida T, Kim H-S, Wataya Y. Synthesis of novel ferrocenyl sugars and their antimalarial activities. Bioorg Med Chem Lett, 2000; 10:1657.

Kadkin ON, Han H, Galyametdinov YG. Synthesis, computational modelling and liquid crystalline properties of some [3] ferrocenophane-containing Schiff's bases and $\beta$-aminovinylketone: Molecular geometry-phase behaviour relationship. J Organomet Chem, 2007; 692:5571.

Kazemizadeha AR, Shajari N, Shapouri R, Adibpour N, Teimuri-Mofradd R, Dinmohammadi P. One-pot, four-component synthesis of 1,3,4-oxadiazole derivatives containing a ferrocene unit and their antimicrobial activity. Appl Organometal Chem, 2016; 30:148.

Kealy TJ, Pauson PL. A new type of organo-iron compound. Nature, 1951; 168:1039.

Kokare DG, Kamat V, Naik K, Nevrekar A, Kotian A, Revankar VK. Evaluation of DNA cleavage, antimicrobial and anti-tubercular activities of potentially active transition metal complexes derived from 2,6-di(benzofuran-2-carbohydrazono)-4-methylphenol. J Mol Struct, 2017; 1127:289.

Kumar K, Pradines B, Madamet M, Amalvict R, Benoit N, Kumar V. 1H-1,2,3-triazole tethered isatin-ferrocene conjugates: Synthesis and in vitro antimalarial evaluation. Eur J Med Chem, 2014; 87:801.

Lakshmi GC, Ananda S, Gowda NMM. Synthesis, characterization, and antioxidant activity evaluation of pyridoxine and its transition metal complexes. Synth React Inorg Met Org Chem, 2011; 41:413.

Liu W, Tang Y, Guo Y, Sun Bo, Zhu H, Xiao Y, Dong D, Yang C. Synthesis, characterization and bioactivity determination of ferrocenyl urea derivatives. Appl Organometal Chem, 2012; 26:189.

Liu Y-T, Lian G-D, Yin D-W, Su B-J. Synthesis, characterization and biological activity of ferrocene-based Schiff base ligands and their metal (II) complexes. Spectrochimica Acta Part A, 2013; 100:131.

Liu J, Li L, Dai H, Fang J. Synthesis and biological activities of new 1H-1,2,4-triazole alcohol derivatives containing a ferrocenyl moiety. Appl Organometal Chem, 2008; 22:237.

Long B, Liang S, Xin D, Yang Y, Xiang J. Synthesis, characterization and in vitro antiproliferative activities of new 13-cisretinoyl ferrocene derivatives. Eur J Med Chem, 2009; 44:2572.

Mahmoud WH, Mahmoud NF, Mohamed GG. Synthesis, physicochemical characterization, geometric structure and molecular docking of new biologically active ferrocene based Schiff base ligand with transition metal ions. Appl Organometal Chem, 2017; e3858.

Molina P, Tarraga A, Lopez JL, Martinez JC. Preparation and heterocyclization reactions of ferrocenylazido ketones. Useful building 
blocks for the synthesis of ferrocenyl-substituted azaheterocycles. J Organomet Chem, 1999; 584:147.

Moore AJ, Skabara PJ, Bryce MR, Batsanov AS, Howard JAK, Daley STAK. Covalently attached ferrocene and tetrathiafulvalene redox systems. J Chem Soc Chem Commun, 1993; 4:417.

Morales-Espinoza EG, Sanchez-Montes KE, Klimova E, Klimova T, Lijanova IV, Maldonado JL, Ramos-Ortiz G, Hernandez-Ortega S, Martinez-Garcia M. dendrimers containing ferrocene and porphyrin moieties: synthesis and cubic non-linear optical behavior. Molecules, 2010; $15: 2564$.

Ochi Y, Suzuki M, Imaoka T, Murata M, Nishihara H, Einaga Y, Yamamoto $\mathrm{K}$. controlled storage of ferrocene derivatives as redox-active molecules in dendrimers. J Am Chem Soc, 2010; 132:5061.

Osman SA, Mousa HA, Yosef HAA, Hafez TS, El-Sawy AA, Abdallah MM, Hassan AS. Synthesis, characterization and cytotoxicity of mixed ligand Mn(II), Co(II) and Ni(II) complexes. J Serb Chem Soc, 2014; 79:953.

Osman SA, Yosef HAA, Hafez TS, El-Sawy AA, Mousa HA, Hassan AS. Synthesis and antibacterial activity of some novel chalcones, pyrazoline and 3-cyanopyridine derivatives based on khellinone as well as $\mathrm{Ni}(\mathrm{II}), \mathrm{Co}(\mathrm{II})$ and Zn(II) complexes. Aust J Basic Appl Sci, 2012; 6:852.

Ott I, Gust R. Non platinum metal complexes as anti-cancer drugs. Arch Pharm Chem Life Sci, 2007; 340:117.

Patra M, Gasser G, Wenzel M, Merz K, Bandow JE, MetzlerNolte N. Synthesis and biological evaluation of ferrocene-containing bioorganometallics inspired by the antibiotic platensimycin lead structure. Organometallics, 2010; 29:4312.

Qiao C, Li J, Xu Y, Guo S, Qi X, Fan Y. Synthesis, structural characterization and electrochemical recognition ofmetal ions of two new ferrocenylhydrazone-based receptors. Appl. Organometal. Chem, 2009; 23:421.

Ran X, Wang L, Cao D, Lin Y, Hao J. Synthesis, characterization and in vitro biological activity of cobalt(II), copper(II) and zinc(II) Schiff base complexes derived from salicylaldehyde and $D, L$-selenomethionine. Appl Organometal Chem, 2011; 25:9.

Rubino S, Pibiri I, Costantino C, Buscemi S, Girasolo MA, Attanzio A, Tesoriere L. Synthesis of platinum complexes with 2-(5-perfluoroalkyl-1,2,4-oxadiazol-3yl)-pyridine and 2-(3-perfluoroalkyl1-methyl-1,2,4-triazole-5yl)-pyridine ligands and their in vitro antitumor activity. J Inorg Biochem, 2016; 155:92.

Sakthilatha D, Deepa A, Rajavel R, Spectroscopic characterization and in vitro antibacterial activity of some novel metal complexes with Schiff base ligands derived from thiosemicarbazide. Synth React Inorg Met Org Chem, 2015; 45:286.

Skehan P, Storeng R, Scudiero D, Monks A, McMahon J, Vistica D, Warren JT, Bokesch H, Kenney S, Boyd MR. New colorimetric cytotoxicity assay for anticancer-drug screening. J Natl Cancer Inst, 1990; 24:1107-1112.

Sondenecker A, Cvengros J, Aardoom R, Togni A, Stereogenic P. Ferrocene-based (trifluoromethyl)phosphanes: synthesis, structure, coordination properties and catalysis. Eur J Org Chem, 2011; 2011:78.

Subbaraj P, Ramu A, Raman N, Dharmaraja J. Synthesis, characterization, and pharmacological aspects of metal(II) complexes incorporating 4-[phenyl(phenylimino)methyl]benzene-1,3-diol. J Coord Chem, 2014; 67:2747.

Sudhir VS, Kumar NYP, Chandrasekaran S. Click chemistry inspired synthesis of ferrocene amino acids and other derivatives Tetrahedron, 2010; 66:1327.

Vogiatzoglou A, Refsum H, Johnston C, Smith SM, Bradley KM, de Jager C, Budge MM, Smith AD. Vitamin B12 status and rate of brain volume loss in community-dwelling elderly. Neurology, 2008; 71:826.

Wakil IM, Ndahi NP, Abubakar MB, Waziri I. Synthesis, Characterization, and Antimicrobial Studies of Propionaldehyde Schiff base Metal (II) Complexes. Chem Res J, 2017; 2:39.

Zheng J, Wu KL, Shi TH, Xu Y. A series of novel ferrocenebased dipeptide receptors for electrochemistry and biological activity. Appl Organometal Chem, 2013; 27:698.

How to cite this article:

Hassan AS, Hafez TS. Antimicrobial Activities of Ferrocenyl Complexes: A Review. J App Pharm Sci, 2018; 8(05): 156-165. 